\title{
The politics of plutonium disposal
}

The new US policy on plutonium disposition is the right one, and efforts to encourage similar action in Russia must be redoubled.

THE decision by the United States to pursue a 'dual track' policy for the disposal of excess plutonium from nuclear weapons is a difficult and necessary step on the long and rocky road to winding down the weapons stockpiles in the United States and Russia. But the ratcheting down of the world's vast stock of fissile material is a task at once more urgent and more complicated than is generally acknowledged.

Hazel O'Leary, the US energy secretary, announced last week that her department will prepare for two means of plutonium disposal simultaneously. It will work out how to mix the element with other, highly radioactive waste and fuse it into large glass or ceramic bricks for storage and eventual burial. At the same time, it will explore the processing of plutonium into mixed oxide (MOX) fuel for burning in civilian nuclear power plants, and subsequent disposition with other spent nuclear fuel.

Left to its own devices, the United States would probably have stuck to the first option. A recently opened vitrification plant at Savannah River, South Carolina, could do the job quite comfortably. The United States has a twenty-year-old policy of keeping the military and civil nuclear-fuel cycles separate from each other, which the MOX option will breach. This administration has no domestic incentive to make trouble with the environmental movement by modifying that policy and distributing MOX containing military plutonium to power plants around the country.

But Russia has an even bigger inventory of excess military plutonium than the United States, and that material is more likely to fall into dangerous hands. Both countries have more than 100 tonnes of military plutonium, of which half is surplus to current military needs. The excess is stored as dismantled weapons cores, or 'pits'. Each weighs about $5 \mathrm{~kg}$ and could be delivered to, say, central London in the glove compartment of a car.

But where the United States sees the excess plutonium as a dangerous liability, Russia (in common with France, Britain and Japan) views it as a potentially valuable energy source. Russia is not prepared to bury it in glass. Had the United States chosen to do so, Russia could have ignored the move and kept its excess plutonium in the warehouse. It could even have made a plausible case that the United States was technically equipped to retrieve the plutonium from glass, in time of need.

An independent commission of Russian and US scientists established earlier this year at the suggestion of Boris Yeltsin, the Russian president - recently pointed out that global security will be best served if Russia and the United States work in tandem on this problem. That means that both countries should pursue both vitrification and MOX fuel burning, the commission said.

Fortunately, the US administration has accepted that advice, and shelved domestic considerations in favour of the larger picture. Its decision has attracted the expected flak from environmentalists. Respected critics of the plutonium economy, such as Paul Leventhal of the Nuclear Control Institute, have attacked it as an "endorsement of plutonium" by the United States, which will, by example, spread the worldwide use of plutonium as a fuel.

These criticisms are not to be taken lightly, but they ultimately represent a triumph of dogmatism over pragmatism. The United States still has 6,500 nuclear weapons deployed, and a larger number in reserve, and spends $\$ 4$ billion a year retaining the capacity to develop still more. The idea that it can lead the world on this issue by moral example is, beyond the confines of a Washington seminar room, laughable. What matters are its actions - in this case, its promise to dispose of its plutonium stock expeditiously while making the compromises necessary to get Russia to do the same. With the US policy in place, the path is now open for the United States to reach agreement rapidly with Russia on the disposal of excess military plutonium, along the lines recommended by the Russian-US commission of scientists, which will report fully in the new year.

Implementation of the US scheme will be difficult enough (although Canada may take the MOX if US power plants cannot be bribed to accept it). Orchestrating the political will and technical means to dispose of weapons plutonium in Russia will present a far sterner challenge. Any solution will have to draw on extensive Western technical and financial assistance. The latter will require the approval of the US Congress, which, despite the best efforts of internationalists such as Senator Richard Lugar (Republican, Indiana), has become increasingly insular and curmudgeonly of late in its approach to aid for Russia.

O'Leary's decision contains - to the environmentalists' horror - some incentives to win congressional support, such as the possibility of a new MOX plant at Savannah River. Hopefully Strom Thurmond (Republican, South Carolina), chair of the Senate Armed Services Committee, has the vision to do the right thing by Russia, with or without such crude incentives.

But even an agreement to dispose of 50 tonnes of excess plutonium in both countries would be only one further step in reducing the world's plutonium inventory. There are, after all, the 50 tonnes still incorporated in the military stockpiles of each country. A START-3 agreement to reduce weapons levels further is awaiting ratification of START 2 by the Russian Duma.

There is, moreover, the growing global inventory of civil plutonium, which now totals around 1,000 tonnes, four-fifths of it in spent fuel and the rest as plutonium oxide or MOX. This material is far less bomb-ready than the pits piling up in Russia and the United States, but it still represents a substantial proliferation hazard. Unlike highly enriched uranium, which can be extracted only by isotopic separation, plutonium could be extracted by relatively simple chemical means. The isotopic make-up of civil plutonium is different from that of weapons plutonium, but it can still be used to make a bomb, as the United States proved in a test in 1962.

The United States has sought to discourage the separation and reprocessing of yet more plutonium at commercial plants in Britain, France and, soon, Japan. It should proceed with plutonium destruction in commercial reactors, while opposing the separation of new plutonium with even greater vigour than before. The nuclear genie will not be back in the bottle until reprocessing plants such as THORP in the United Kingdom are closed down but that can only be regarded as a long-term objective.

In the meantime, Russia is the main proliferation issue. O'Leary has moved with some skill to neutralize parties in the United States hostile to foreign aid and oblivious to the importance of improved management of Russian nuclear material. The onus is now on the Congress to provide the modest sums of money needed to support plutonium disposition at home and abroad. $\quad \square$ 